$9(1)(2020) 53-61$
Indonesian Journal of Early Childhood
Education Studies

\title{
Does Play Help to Learn Vocabulary? A Case Study on Primary School Teachers' Attitude of Dhaka City in Bangladesh
}

\author{
Alpona Shirin \\ DOI: http://dx.doi.org/10.15294/ijeces.v9i1.38891 \\ Universitas Islam Negeri Sunan Kalijaga Yogyakarta, Indonesia
}

\section{History Article \\ Submitted 4 April 2020 Revised 13 May 2020 \\ Accepted 4 June 2020 \\ Keywords \\ Play-based learning; Game, Joyful Learning; Vocabulary; Qualitative Study; Instruc- tional technology; Attitude; Bangladesh}

\begin{abstract}
This study focused on teachers' attitude towards using games in teaching-learning activities of learning vocabulary. The purpose of this research is to explore teachers' attitude to the use of a game for learning vocabulary of the students. A qualitative study was conducted with 12 teachers of Azampur Government Primary School of Dhaka city, Bangladesh to gain in depth knowledge of the issues. An everyday game of children named 'Tic-tac-toe' was chosen for teachers to teach vocabulary rather traditional process of memorizing. Then, semi-structured focus group interviews were used as tool to collect data from teachers after observing students playing the game. Data was then analyzed for thematic contents by standard content analysis framework which yielded six major themes such as play-based teaching strategy, language development, classroom environment, learning by doing approach, acceptance and barriers on adopting play-based strategy. Overall, findings showed positive attitude towards using game for learning vocabulary of a foreign language. The implications of this study imply that the themes can be effective in classroom practice of Bangladeshi classroom.
\end{abstract}

\section{How to Cite}

Shirin, A. (2020). Does Play Help to Learn Vocabulary? A Case Study on Primary School Teachers' Attitude of Dhaka City in Bangladesh. Indonesian Journal of Early Childhood Education Studies, 9(1), 53-61. 


\section{INTRODUCTION}

This study focused on how teachers perceive the strategy of using a game on teachinglearning process of vocabulary. Vocabulary is a fundamental segment for early literacy achievement (Roskos et al. 2008). In teaching-learning of any language, the primary importance is vocabulary (Widaningsih, 2009). Surprisingly, vocabulary is often ignored mostly in second language classes (Fernández et al., 2009). Study has mostly emphasized to the importance of vocabulary learning for language learning like English (DeCarrico, 2001). Generally, language learners face significant difficulties in memorizing large vocabularies. Researcher showed that children who enter school with poor vocabularies regularly experience troubles in learning (Walker et al. 1994). Students cannot get others idea and express their ideas without enough vocabulary (Lessard-Clouston,2013). In addition, students are having a strong distaste of learning vocabulary in consecutive methods like memorizing, writing on papers, adapting inactively through teachers' explanations which has made extreme issues with learning abilities (Nguyen \& Khuat, 2003 \& Uberman, 1998). However, students prefer learning language in a casual environment, for example vocabulary games (Nguyen \& Khuat, 2003). Students can learn almost 80 percent what they are exposed to from joyful and communicative classes (Nguyen \& Khuat, 2003). As per Freeman (2000), students appreciate communicative engagement in the classroom. He stated that plays can provide a constructive competition.

Though defining play is a difficult idea, it is easy to recognize. Play is an important part of childhood where children can effectively engage in different types of activities with a partner or group. Play can offer effective learning approach and can achieve a priority method of teaching in childhood education (Moyles, 2014). Coinciding with the arise of this concept, implementing game as a learning tool became a source of interest among the teachers (Aziz \& Majzub, 2011; Bakhsh, 2016; Opel, et al., 2009; Kamal \& Shahadur, 2019). In order to create effective impact on teaching-learning process of vocabulary learning teachers need to create more specific learning activities to provide their students with more support (Prioty, 2014). The activity time of a play can give a successful learning experience for children and help them achieve knowledges as play permits children to be inventive while building up their own minds (Anderson-McNamee, \& Bailey, 2010). Series of studies investigated about the effectiveness of play based teachinglearning process in different contexts (Ramadhaniarti, 2016; Ali, et al., 2011; Bakhsh, 2016; Chen \& Chung, 2007; Han, et. al., 2010; Chan \& Lin, 2000; Jiang, 2008; Kuo, 2008). In Bangladesh, there is also some studies (Proity, 2014; Opel, et al., 2009; Kamal \& Shahadur, 2019) regarding the impact on students in joyful teaching-learning. However, there is dearth of studies in terms of attitude of teachers in implementing play-based learning method. The aim of this study was to analyze teachers' attitude towards the impact of implementing a casual game for learning vocabulary which has not been examined in previous research.

With regards to this purpose, the study applied a qualitative approach to understand Bangladeshi primary school teachers' attitude on impact of using a game on vocabulary teaching-learning. The main unit of analysis was to analyze teachers attitude based on thematic content analysis. This study expected that it would be useful for the contribution of strategy in teaching vocabulary and findings will be useful for the teachers who are interested in changing their teaching strategy for vocabulary learning.

The purpose of this research is to explore teachers' attitude to the use of a game for learning vocabulary of the students. To achieve the purpose of this study, the following sub questions guided my research- How do teachers perceive the use of a game for learning vocabulary?

\section{METHOD}

A qualitative methodology was adopted to explore the attitude of teachers about play based learning. The data was collected by semi-structured focus group interviews of the primary school teachers. The focus was on knowledge of teaching strategy in terms of vocabulary, language development through play, teaching- learning environment in play-based strategy, knowledge and confidence in change in teaching practice, students' learning approach and future interventions towards teaching practice in vocabulary. The guide was subjected to validation and reliability assessment prior to data collection. This qualitative study can be categorized as a case study because the research was carried out in a limited or small-scale single case. To analyze the obtained data, descriptive data analysis for thematic analysis was employed. In analyzing data, the steps followed are transcribing, coding and interpreting the data. The first step is transcribing the data because interview needs to be transcribed to enab- 
le data analysis for a study. (Gibbs 2007; Bailey 2008). The researcher used a recorder at the time of focus group interviews and then transcribed the focus group interviews herself. Secondly, the data were coded in form of labelling as coding includes a process of defining the data (Charmaz, 2006). From the specific coding, researcher then grouped the codes into themes. The themes are of principal attributes and of principal actions. The researcher did narrative analysis considering the focus of attitude and different experiences of each teacher.

The respondents of the study was 12 teachers from grade II, III \& V (which has two sections in each grade) of Azampur Govt Primary School of Dhaka city. Before interviewing the teachers, researcher did observation for half an hour in each grade II, III \& V English classroom in the school to see the students' participations to the 'Tic-tac-toe' game which was conducted by the teacher in teaching English vocabulary. Three Focus Group interviews are conducted in which four teachers from each grade had participated in one focus group interview. The game and the focus of the interviews was pilot tested within four students and a home tutor. The instrument was subjected to validation and reliability assessment prior to data collection. Qualitative experts at University of Dhaka validated the interview focus by using a combination of argumentative and cumulative techniques. Researcher choose a casual game 'Tic-tac-toe' as a word game for teaching vocabulary lessons. The pilot test gave an opportunity to the researcher to make amendments to the tool carried out in the main research.

Tic-tac-toe (otherwise called noughts and crosses or Xs and Os) is a paper-and-pencil game for two players who take turns marking the spaces in a $3 \times 3$ framework. The player who succeeds in placing three of their marks horizontally, vertically or diagonally wins the match. In this research, children provided some flip cards of English alphabets instead of $\mathrm{X}$ and Os. Two players were provided to collect alphabets randomly, 13 alphabets for each. For grade II the framework was $3 \mathrm{X} 3$, grade III the framework was $4 \mathrm{X} 4$, and $5 \mathrm{X} 5$ was for grade $\mathrm{V}$. When the player formed a meaningful word horizontally, vertically or diagonally, he scored accordingly the number of alphabets. For instance, when a player formed 'DONE' vertically, he scored 4 and another player formed 'TO' horizontally where he scored 2. At the end of the game, the total score added, and the highest scorer won the match. The grids were selected regarding age and vocabulary capacity of the students and pilot tested within four students.
In this research, two teachers were selected from each class who conducted the game in a class. The teachers welcomed the students for participating the game willingly, then formed some twoparticipant groups for implementing the game in a break time of half an hour. The researcher briefed the teachers the play with instructions for implementing. In two sections of three grades, 12 teachers were conducted the game with about 50 students. The purpose of these activities was to explore the effectiveness of a word game for effective teaching-learning. The researcher took the role of observer for understanding whether the game was working effectively or not to improve vocabulary learning. Students were unaware that they were being observed. After the end of the implementation of the game, the researcher conducted focus group interviews with the teachers where the focus was to explore teachers' attitude to implement the game for teaching vocabulary.

\section{RESULT AND DISSCUSSION}

Twelve primary school teachers of Dhaka city were interviewed. Majority $(n=10)$ of the participants were from age group 30-40 with 5 and above year working experiences. Two respondents were of 20-30 age group with 1-2 year working experience. The findings from the interviews of teachers revealed teachers' attitude in multiple ways. Though most of the teachers explored using games in a positive way, some teachers stated some negative impacts also. The focus group interviews produced six themes which explain teachers' attitude towards the effectiveness of using a game for learning vocabulary.

During the interviews the participants were asked for their concept about implementing a play for teaching vocabulary. Majority of the participants stated that teaching through a game was completely a new concept as a teaching strategy. Participants of this study mostly agreed that they used traditional method of memorizing list of words for teaching vocabulary. Only one recently joined teacher having B.ed degree have expressed his updated knowledge about play-based teaching strategy. This may be attributed to the fact that newly joined teacher with experience of 1 to 2 years feel interested about updated teaching strategy. However, all the teachers $(n=12)$ agreed that suggested play-based activities assist them to enhance their teaching strategy for teaching vocabulary and playing a vocabulary game do also help to improve student's capacity of learning vocabulary than using traditional method. They hardly thought about any strategies that could 
help this way.

"When I was contacted to implement a game, I supposed that it will be a waste of class time. But surprisingly, at the end of the game whole class learned more words than I imagined."

"It was fun; it's the first time I am using a game for teaching vocabulary. Students had to recall the words or make new words and put it intentionally to win the game. I feel that it helped not only to remember those words but also to learn new words to become a winner of the game."

The teacher having updated knowledge about teaching methodology expressed views as:

"I have completed a course on instructional technology on my Bachelor in Education (B.ed). I achieved a diversified knowledge on teaching materials on that course. Implementing a game seems very effective to me for vocabulary learning of students."

\section{Language development through play}

Participants were asked about the impact of play on students' vocabulary learning. Majority commented that students can achieve a greater quantity of meaningful vocabularies and they were not also afraid of making mistake in saying a new word. Respondents also said that students were conscious about the spelling of the words, learning diverse words on a single letter, knowing the precise pronunciations and meanings of different words, because it was the prerequisite for winning the game. One teacher mentioned that,

"In my classes I always gave importance to the pronunciation, spelling and writing of words for memorizing vocabulary as listening, reading, writing and speaking are the basics of learning English. However, this game includes all of these language skills by playing it which was very effective."

Majority of the participants stated that learners instinctively recognized the importance of vocabulary to their language learning by this game. Children had to select an alphabet, paused to think and hit another alphabet by turn to make a meaningful word to win which represents the development of language skills. Another advantage revealed is that students' anxiety towards language learning decreases at the time of game employing. Regardless, all of the grades ii,iii \& V this game create an impact on vocabulary learning of students.

"In language classes, children feel stressful because they have to master the language which is unknown to them but by playing this game, they hardly recognized that they already learned the language."
Classroom environment in play-based learning

Participants was interviewed about the classroom environment after implementing the game. Majority showed their positive views towards the classroom environment and stated that they literally learned how to organize a classroom for creating an effective teaching-learning environment by maintaining focus on the whole class in order to keep activities organized smooth.

"The engagement of students was really admirable. Students were so enthusiastic about playing the game, they were asking questions where any complications arose and confirming the rules and meaning of words from the teachers at the time of scoring. This effective way of engaging students taught me a classroom management trick."

"I noticed while completing the games, peers only talked only about how they can win, I rarely heard students to chat within peers which was an excellent idea of engaging student"

The game indeed created an interacting classroom environment which also includes friendly teacher-student relationship. Through researcher observation it could also be seen that students were interested to play the game willingly because of having scopes to compete with one another. Contrarily, two respondents faced challenges in implementing the game.

"Children sometimes moved a lot and talked too much when they were excited which made it hard to control them. As a result, it made noise and unorganized classroom."

\section{Acceptance of play-based teaching-learning}

In the interviews, respondents were asked to express their views to accept the change student's participation in play-based teachinglearning. Most of the participants frequently said that game relieved the children from being bored in classrooms where they sit passively. Students' positive attitude towards playing games may show that children really enjoyed the game. This may mean children want to have the opportunity to play games in the classroom, as they provide an active participation in the classroom. Researcher also observed student's active participation in the game. Considering the impact, majority of the teachers were ready to accept the change, but they recommended proper training from the govt to implement such strategy.

"All of the students were eager to participate the game, even after one round, some shy students also raise their hands up to play the game which gave me immense pleasure. Yes, it is necessary in classroom to implement such play-based activities."

"Every student was desperate to be the win- 
ner. So, they are collecting new words to play the game again and again. This kind of effective activity definitely can make good standards of teaching."

\section{Learning by doing approach}

During the interview, researcher investigated teachers' attitude towards students learning approach for the play-based activities. One teacher mentioned, "when children touch something, they realize what the object is and how it feels; when they do some action, they get to know the meaning". As in the game, children were provided alphabets through flip cards first, they were recognizing the alphabets and then by placing in a right order they got the actualization. Majority of the participants suggested the activity as learning by doing. Moreover, by maintaining the rules of the game and following that cooperatively with peers and teachers, students also develop a social behavior by playing the game. Through observation researcher also observed the same.

\section{Barrier towards adoption of play-based strat- egy}

In terms of barrier towards adoption of play-based teaching-learning activities, participants of primary school teachers of Bangladesh identified limitations like lack of training programs regarding instructional technology, poor salary structures of primary school teachers, teacher-students ratio and spaces in classrooms.

"There are barriers as primary school teachers have very poor salary. Most of the time teachers do not feel interested to give an extra effort to make lessons interesting. Government did not also arrange proper training for updated teaching strategies."

"Basically, the teacher-student ration in Bangladeshi primary school is too high to implement such type of strategy. Implement a game in a congested classroom within at least 60 students will be a real challenge."

Implementing a play for teaching-learning activities seems a completely new idea at the perspective of Bangladeshi primary school teachers. Although several studies are reported in literature regarding joyful learning and play-based activities (Chowdhury \& Rivalland, 2012; Banu, 2014; Begum, 2011), there is paucity of information for Bangladeshi teachers for adopting such new strategy. The present study suggested multiple factors that must be addressed to bring change in teaching practice of primary school teachers in Bangladesh.

A handful of our respondents had a clear idea and concept of play-based teaching strategy; however, majority of the respondents were unaware of implementing a game as a learning tool. This warrants insufficient exposure and practicing updated skills and knowledges as per trends and creativity. In primary schools of Bangladesh having B.Ed and M.Ed degree is optional for teaching profession which creates dearth of updated knowledge about instructional technology. Previous studies of different contexts have suggested that (Lynch, 2015; Pyle \& Danniels, 2017; Bulunuz, 2012; Van-Oer \& Duijkers, 2013) early schoolteachers should engage themselves in play-based teaching method with proper instructional technology. According to Allen (1983), games are important in teaching vocabulary because they highlight the necessary and important words to achieve the objectives of the game. Vernon (2009) argued that games are effective tools to teach vocabulary to young learners. Therefore, play-based strategy creates positive attitude towards learning and teaching. The current study also supports that in showing the benefits of playbased teaching method for learning vocabulary. In Bangladesh, most of the teachers emphasized memorization of textbook vocabularies more than play-based learning (Banu, 2014; Chowdhury \& Rivalland, 2016). Therefore, in order to create an effective impact on students learning teachers should employ new teaching strategies like play for vocabulary learning. The findings of this study can contribute for primary school teachers to improve their knowledge and teaching strategy for teaching vocabulary in education sector of Bangladesh.

Learning through games could encourage the operation of certain psychological and intellectual factors of language skills which could facilitate communication heightened self-esteem, motivation towards language learning and reinforcing learning (Huang, 2005). To the mastery of English language skills, students have to know the vocabulary of the language such as a list of words with meaning which supports their skills' improvement (Linse \& Nunan 2005). In addition, games may involve all four language skills, speaking, writing, listening, and reading (Lee, 1995). In other contexts (Thomas, et al., 2011; Stagnitti, et al., 2016; Nicolopoulou, et al., 2015) it is confirmed that play-based teaching strategy can contribute to children's learning of language skills which is also suggested by the findings of this study. In Bangladesh, the current scenario of learning the English language includes learning vocabulary, grammar, reading, and translation. Students may face problems to understand concepts, as they usually get is something abstract. The syllabus remains fixed and the teachers have 
the freedom to choose the teaching material. In fact, students are given marks on class-performance, which may on speaking or vocabulary learning. They feel shy and do not want to speak in front of the class. Since children are being prepared bilingual for higher studies in Bangladesh, students need to use English outside the class from the very beginning of learning. The traditional way of learning vocabulary by mere copying and recalling has shown to be less effective. Meanwhile, games are also being considered as a time-consuming activity in most English classrooms. Studies also suggests that play-based method can develop learning skills in early childhood education of Bangladesh (Chowdhury, \& Rivalland, 2012; Banu, 2014). Therefore, findings of this study for implementing a game for teaching vocabulary can motivate the primary school teachers of Bangladesh for effective language development through game. The study has shown that those having more experiences had no clear idea about modern teaching strategy. On the contrary, young teachers having B.Ed with experience ranging from 1 to 2 years seem to be more updated theoretically. Therefore, it is important that the students should be educated properly about their extended roles while working in teaching profession during their undergraduate studies. It should also be addressed by the government to provide proper trainings to primary school teachers. This will create awareness among teachers to practice more updated strategy in their teaching.

The findings of the study supported several studies stating that teachers have to understand the students' characteristics for creating an effective environment for learning (Brown, 2001; Cameron, 2001). According to Moon (2009), "Interaction is the basic source of language input". Teachers need to provide children a communicative atmosphere where they could express themselves for creative language skill (Halliwell, 1992). Games create an atmosphere of effective communication where children can communicate before, during, and after the game (Wright, et al., 2005). Moreover, games create a fun and relaxed atmosphere where children could learn fast and retain words better (Nga, 2003 \& Uberman, 1998). However, understanding games will assist teachers in finding and creating casual games that help their students to learn while they play (Rixon,1981). Games also encourage learners to keep interested in learning from which teacher can use students focus to concentrate in a single topic within shortest possible time (I-Jung, 2005). Basically, effective classroom management includes strategies that create a safe, fair and rule-based learning environment for students to flourish in (Emmor \& Evertson, 1981). Thus, play-based activity flourished in other contexts as a mean of time and classroom management. Bangladesh suffers from excessive students in one classroom where classroom management remain a vital issue. Research suggested that Bangladesh needs low cost material and skilled classroom management to develop new ways for language learning (Begum, 2011). In this study, researcher used a low-cost tool as a game and findings suggested an effective time and classroom management. Thus, the findings of this study can contribute to the classroom management skill of primary school teachers of Bangladesh.

Using games in teaching not only enhances children's motivation, but also provide a reinforcement to use the language (Lewis \& Bedson, 1999). While playing in a small group, students may develop their skills of disagreeing in a polite way, ask for help, and work with others (Jacobs $\& \mathrm{Liu}, 1996)$. They encourage cooperation, team spirit, competition, and turn taking (Ersoz, 2000 \& Orlick, 2006). "The more decisions the learners make about a word, and the more cognitively demanding these decisions, the better the word is remembered" (Thornbury, 2002). Accordingly, it seems that using games enhances students' ability to recall the words which store the words into students' working memory and hopefully the long-term memory. The findings are in a line with studies suggested students can learn vocabulary more quickly and easily by doing activities during game playing. Furthermore, children learn best by doing and by acting in the world (Angelova \& Lekova, 1995; Atake, 2003; Deng, 2006; Pound, 2014). In Bangladesh, students-centered learning is yet to adopt (Biswas \& Roy, 2010). Therefore, findings of this study can contribute to adopt the student-centered learning for effective learning by doing approach of students.

Teachers' positive attitude towards games for teaching vocabulary showed that students and teachers both really enjoyed the game. This indicates that the students really want to have the scope to play games in classroom, and teachers also can provide an active and supportive environment in the classroom. Furthermore, some teachers faced trouble in implementing the game regarding classroom management. Therefore, teaching strategy through game need proper instructions with time bindings. Firstly, teacher must understand the game and how to conduct it properly. Then, teachers will encourage every student to take part in game and supervise them accordingly. For effective teaching-learning, the- 
re should be a balance between game, number of vocabularies, time, effort, and instructions in native language. Thus, teachers will capable of balancing all the challenges while using games in teaching vocabulary. The respondents expressed their views about the readiness and acceptance of change in teaching strategy. The transformation can be challenging in developing country like Bangladesh. This study reports several barriers like teacher-student ratio, poor salary structures and classroom spaces. The government needs to play a proactive role to rise teachers' salary high, providing proper training and imposing strict laws about classroom environment. Those who completed a Bachelor and Master of Education should be prioritized in engaging with teaching profession with high salary scale. In addition, the government should impose compulsory training from teachers training institute to every primary school for better outcome in teaching strategy.

Curriculum of primary and preschool should also create learning opportunities directly into play, so that the learning can match the development process. If primary school teachers of Bangladesh employ play-based teaching method, academic performance of primary school students will also increase. Students will also feel attracted to come to the school which may also decrease the dropout rate at primary level. Therefore, teachers should definitely incorporate joyful teaching methods into their teaching.

\section{CONCLUSION}

This study shows a lack of awareness among primary school teachers about implementing play-based activity for vocabulary teaching. However, teachers' attitude was positive towards accepting change in teaching strategy provided the government plays its role to remove the barriers for the implementation and ultimate benefit of primary education. The study also reveals that games can contribute to vocabulary learning in an effective and pleasant atmosphere with proper time and classroom management. The game used in this research can be played not only in the classroom but also anywhere students want to play with their peers which involves active language learning. The major contribution of the study is its demonstration of a large effectiveness of teaching-learning vocabulary in Bangladeshi context. This research demonstrated that employing games for teaching vocabulary could be improved significantly with benefits to the children and teachers. In Bangladesh, the importance of quality primary education has been acknowledged by the government. As a result, newer concept of teaching-learning strategy has been channeled. However, learning vocabulary through games can be one powerful and intriguing way to connect in any classrooms. Thus, games may lead students towards the goal of improving communicative competence by their teachers and surroundings.

\section{REFERENCES}

Ali, A., Aziz, Z., \& Majzub, R. (2011). Teaching and learning reading through play. World Applied Sciences Journal, 14(4), 15-20.

Allen, V. F. (1983). Techniques in Teaching Vocabulary. New York: Oxford University Press.

Anderson-McNamee, J. K., \& Bailey, S. J. (2010). The importance of play in early childhood development. Montana State University Extention, 1-4.

Angelova, T. G., \& Lekova, B. C. (1995). A Model of Early Childhood Foreign Language Education through Playing Motoric Games.

Atake, K. (2003). Using Games To Teach English in Japanese Junior High School.

Bailey, J. (2008). First steps in qualitative data analysis: transcribing. Family Practice, 25(2), 127-131.

Bakhsh, S. A. (2016). Using Games as a Tool in Teaching Vocabulary to Young Learners. English Language Teaching, 9(7), 120-128.

Banu, M. S. (2014). Teachers' beliefs and perceptions of quality preschool education in Bangladesh: A postcolonial analysis. Australasian Journal of Early Childhood, 39(4), 37-44.

Bar-Yam, M., Rhoades, K., Booth Sweeney, L., Kaput, J., \& Bar-Yam, Y. (2002). Complex systems perspectives on education and the education System. New England: Complex Systems Institute.

Begum, R. (2011). Prospect for cell phones as instructional tools in the EFL classroom: A case study of Jahangirnagar University, Bangladesh. English Language Teaching, 4(1), 105-115.

Biemiller, A., \& Slonim, N. (2001). Estimating root word vocabulary growth in normative and advantaged populations: Evidence for a common sequence of vocabulary acquisition. Journal of Educational Psychology, 93(3), 498.

Biswas, T., \& Roy, G. (2010). Important Consideration in Planning Student-Centered Education in Bangladesh. Primary Education Journal, 4(1).

Bransford, J. D., Brown, A. L., \& Cocking, R. R. (2000). How people learn (Vol. 11). Washington, DC: National academy press.

Brown, H. D., \& Principles, T. B. (2001). An interactive approach to language pedagogy. NY: Longman, 430.

Bruner, Jerome. (1982). The formats of language acquisition. The American Journal of Semiotics 1(1), 1-16.

Bulunuz, M. (2012). Developing Turkish Preservice Preschool Teachers' Attitudes and Understanding about Teaching Science through Play. International Journal of Environmental and Science 
Education, 7(2), 141-166.

Cameron, L. (2001). Children learning a foreign language. Lynne Cameron, Teaching Languages to Young Learners, 1-20.

Chan, Y. C., \& Lin, L. C. (2000). Competitive and cooperative games in EFL elementary school classroom. Proceedings of ROCMELLA, 123-147.

Charmaz, K. (2006). Constructing grounded theory: A practical guide through qualitative analysis. Sage.

Chen, C. M., \& Chung, C. J. (2008). Personalized mobile English vocabulary learning system based on item response theory and learning memory cycle. Computers \& Education, 51(2), 624-645.

Chowdhury, J. H., Chowdhury, D. K., Hoque, M. S., Ahmad, S., \& Sultana, T. (2009). Participatory evaluation: Causes of primary school drop-out. Dhaka: Directorate of Primary Education.

Chowdhury, N. N., \& Rivalland, C. (2012). Value of Play as an Early Learning Instrument in Bangladesh Context: A Sociocultural Study. Australasian Journal of Early Childhood, 37(4), 115122.

Chowdhury, N. N., \& Rivalland, C. (2016). Conceptualising play as pedagogy in the ECE context of a developing country: The case study of Bangladesh. MIER Journal of Educational Studies, Trends and Practices, 1(2).

Christie, J. F., \& Roskos, K. A. (2006). Standards, science, and the role of play in early literacy education. In Playlearning: How play motivates and enhances children's cognitive and social-emotional growth, ed. Dorothy G. Singer, Roberta M. Golinkoff, and Kathy Hirsh-Pasek, 57-73.

Decarrico, J. S. (2001). Vocabulary learning and teaching. Celce-Murcia, M.(ed.). Teaching English as a second or foreign language.

Deng, Q. H. (2006). A study of using games in primary school English teaching. Master's thesis, Northwest Normal University, Shensu province, Chine.

Emmer, E. T., \& Evertson, C. M. (1981). Synthesis of Research on Classroom Management. Educational Leadership, 38(4).

Englebright, J. F. (n.d) Retrieved from http://www. earlychildhoodnews.com/earlychildhood/article_view.aspx?ArticleID $=240$

Ersoz, A. (2000). Six games for the EFL/ESL classroom. The internet TESL Journal, 6(6), 7-11.

Fernández, R. F., Prahlad, S. R. R., Rubtsova, E., \& Sabitov, O.(2009). Collocations in the vocabulary English teaching as a foreign language. Acimed, 19(6), 1-5

Gibbs, G. R. (2018). Analyzing qualitative data (Vol. 6). Sage.

Gnoinska, A. (1998). Teaching Vocabulary in Colour. In Forum, 36(3), 7-12.

Halliwell, S. (1992). Teaching English (Vol. 209). Longmann.

Han, M., Moore, N., Vukelich, C., \& Buell, M. (2010). Does play make a difference? How play intervention affects the vocabulary learning of atrisk preschoolers. American Journal of Play, 3(1),
$82-105$.

Huang, J. (2005). A diary study of difficulties and constraints in EFL learning. System, 33(4), 609621.

Huyen, N. T. T., \& Nga, K. T. T. (2003). Learning vocabulary through games. Asian EFL Journal, 5(4), 90-105.

Islam, M. J., \& Bari, I. S. (2012). Implementation of CLT in Bangladesh and Thailand: Problems and challenges. Outlooks: VUB, 2(1).

Jacobs, G. M., \& Liu, K. K. (1996). Integrating language functions and collaborative skills in the second language classroom. Online Submission.

Jiang, L. (2008). The use of games in teaching children English. Unpublished masters thesis, Shandong University, Shandong province, China.

Johnson, J. E., Christie, J. F., \& Wardle, F. (2005). Play, development, and early education. Pearson: Allyn and Bacon.

Jung, I. (2005). ICT-pedagogy integration in teacher training: Application cases worldwide. Journal of Educational Technology \& Society, 8(2), 94-101.

Kamal, M. M., \& Chowdhury, M. S. R. The Role of Head Teachers In Ensuring Joyful Learning Environment in Goverment Primary School (GPS) of Bangladesh.

Kuo, Y. L. (2008). The effect of games in fifth graders' English speaking ability in an elementary school in Taipei County. Unpublished master s thesis of National Taipei University of Education.

Kyriacou, C. (2001). Teacher stress: Directions for future research. Educational Review, 53(1), 27-35.

Larsen-Freeman, D. (2000). Techniques and principles in language teaching. Oxford University.

Lee, S. K. (1995). Creative games for the language class. Forum. 33 (1).

Lessard-Clouston, M. (2013). Teaching Vocabulary. TESOL International Association. 1925 Ballenger Avenue Suite 550, Alexandria, VA 22314.

Lewis, G., \& Bedson, G. (1999). Games for children. Oxford University Press.

Linse, C. T., \& Nunan, D. (2005). Practical English language teaching: young learners/by Caroline T. Linse; David Nunan, series editor. New York: McGraw-Hill/Contemporary.

Lynch, M. (2015). More Play, Please: The Perspective of Kindergarten Teachers on Play in the Classroom. American Journal of Play, 7(3), 347-370.

Maleq \& Islam. (2009). Child Bangladesh: An Analysis on The Global Perspective. Teachers World, pp. 121-130.

McCallum, G. P. (1980). 101 word games for students of English as a second or foreign language. Oxford University Press, USA.

Ministry of Education (2010). National Education Policy, Government of Bangladesh.

Moon, J. (2009). The teacher factor in early foreign language learning programmes: The case of Vietnam. The age factor and early language learning, 40, 311.

Moyles, J. (2014). The excellence of play. McGraw-Hill Education (UK). 
Mullick, J. I., \& Sheesh, S. (2008). Teachers quality and teacher education at primary education sub-sector in Bangladesh.

Mustafa, M. N., Chowdhury, L., \& Kamal, M. S. (2012, May). Students dropout prediction for intelligent system from tertiary level in developing country. In 2012 International Conference on Informatics, Electronics \& Vision (ICIEV) (pp. 113-118). IEEE.

Mustapha S. M., Abd Rahman N. S. N. \& Yunus M. Md. (2010). Perceptions towards classroom participation: A case study of Malaysian undergraduate students. Procedia Social and Behavioral Sciences. 7(C), 113-121.

Nguyen, T. T. H., \& Khuat, T. T. N. (2003). The effectiveness of learning vocabulary through games. Asian EFL Journal Quarterly, 5(4), 238-245.

Nicolopoulou, A., Cortina, K. S., Ilgaz, H., Cates, C. B., \& de Sá, A. B. (2015). Using a narrativeand play-based activity to promote low-income preschoolers' oral language, emergent literacy, and social competence. Early Childhood Research Quarterly, 31, 147-162.

Opel, A., Ameer, S. S., \& Aboud, F. E. (2009). The effect of preschool dialogic reading on vocabulary among rural Bangladeshi children. International Journal of Educational Research, 48(1), 12-20.

Orlick, T. (2006). Cooperative games and sports: Joyful activities for everyone. Human kinetics.

Oxford, R., \& Crookall, D. (1990). Vocabulary learning: A critical analysis of techniques. TESL Canada Journal, 1(1), 9-30.

Park, J. (2009). A Discourse on Teacher Development in Bangladesh: Insights into How and Teachers Interpretation and Use of Progressive Teaching Methods, 53rd Annual Conference of the Comparative and International Education Society.

Piaget, J. (1976). Piaget's theory. In Piaget and his school (pp. 11-23). Springer, Berlin, Heidelberg.

Pound, L. (2014). How children learn. Foundations of Early Childhood: Principles and Practice, 103.

Proity, S. H. (2015). Effect of joyful teaching on grade IV students' academic performance in science. International Journal of Science and Research, 4(10), 1232-1240

Pyle, A., \& Danniels, E. (2017). A continuum of playbased learning: The role of the teacher in playbased pedagogy and the fear of hijacking play. Early Education and Development, 28(3), 274-289.

Rahman, S. (2010). Quality of Education in Bangladesh. British Broadcasting Corporation (BBC) Radio.

Ramadhaniarti, T. (2016). Teaching English Vocabulary through Game: Views from the Students. Proceedings of ISELT FBS Universitas Negeri Padang, 4(2), 382-387.

Rixon, S. (1981). How to use games in language teaching.

Rogers, C. \& Sawyers, J. (1988). Play in the lives of children. Washington, DC: NAEYC.
Roskos, K., Ergul, C., Bryan, T., Burstein, K., Christie, J., \& Han, M. (2008). Who's learning what words and how fast? Preschoolers' vocabulary growth in an early literacy program. Journal of Research in Childhood Education, 22(3), 275-290.

Shirin, A. (2020). Determining the relationship between academic achievement and prosocial behavior of secondary school students in Dhaka City.

Stagnitti, K., Bailey, A., Hudspeth Stevenson, E., Reynolds, E., \& Kidd, E. (2016). An investigation into the effect of play-based instruction on the development of play skills and oral language. Journal of Early Childhood Research, 14(4), 389-406.

The Daily Star (2010). Teaching methods by Khan, H. Retrieved from: https://archive.thedailystar. net/newDesign/newsdetails.php?nid=161608.

Thomas, L., Warren, E., \& DeVries, E. (2011). Playbased learning and intentional teaching in early childhood contexts. Australasian Journal of Early Childhood, 36(4), 69-75.

Thornbury, S. (2006). How to teach vocabulary. Pearson Education India.

Uberman, A. (1998). The use of games for vocabulary presentation and revision. In English Teaching Forum, 36(1), 20-27.

Van Oers, B., \& Duijkers, D. (2013). Teaching in a playbased curriculum: Theory, practice and evidence of developmental education for young children. Journal of Curriculum Studies, 45(4), 511-534.

Vandenberg, B. (1986). Play theory. In G. Fein \& M. Rivkin, (Eds.), The young child at play, (pp. 1722). Washington, DC: NAEYC.

Vygotsky, L. (1978). Mind in Society. Harvard University Press.

Walker, D., Greenwood, C., Hart, B., \& Carta, J. (1994). Prediction of school outcomes based on early language production and socioeconomic factors. Child Development, 65(2), 606-621.

Wells, G. (1983). Talking with children: The complementary roles of parents and teachers. In Early childhood development and education: Readings in psychology, ed. Margaret C. Donaldson, Robert G. Grieve, and Chris Pratt, 127-50.

Widaningsih, R. (2009). Increasing vocabulary mastery using crossword puzzle technique in inclusion program. (Unpublished research paper for the Bachelor Degree of Education). English Department, School of Teacher Training and Education, Muhammadiyah University of Surakarta.

Wright, A., Betteridge, D., \& Buckby, M. (1992). Games for language learning. Ernst Klett Sprachen.

Wu, W. H., Chiou, W. B., Kao, H. Y., Hu, C. H. A., \& Huang, S. H. (2012). Re-exploring gameassisted learning research: The perspective of learning theoretical bases. Computers \& Education, 59(4), 1153-1161. 